\title{
Ambient Air Pollutions along a Major South-Western Nigerian Road
}

\author{
Gbadebo Omoniyi Adeniyi, Olusegun Ismail Lawal, Samuel Okemute Egwenu, \\ Jacob Ademola Sonibare, and Funso Alaba Akeredolu
}

\section{ABSTRACT}

This study investigated the air pollutants in the ambient air of a typical intercity highway in Nigeria. This was to assess the effect of vehicular emission on air quality along the highway. The results showed that NOx concentrations ranged from $9.9 \pm 3.2$ to $33.8 \pm 3.3 \mu \mathrm{g} / \mathrm{m}^{3}$ during the wet season and $19.0 \pm 1.2$ to $35.4 \pm 2.3 \mu \mathrm{g} / \mathrm{m}^{3}$ during the dry season. Sulfur dioxide measured along this highway ranged from $49.7 \pm 38.1$ to $219 \pm 18.1 \mu \mathrm{g} / \mathrm{m}^{3}$ during the wet season while dry season concentration ranged from $89.1 \pm 20.9$ to $225.4 \pm 57.9 \mu \mathrm{g} / \mathrm{m}^{3}$. The TSP during the wet season ranged from $54.4 \pm 25.6$ to $126.8 \pm 25.6 \mu \mathrm{g} / \mathrm{m}^{3}$. These values were below the limits of $250 \mu \mathrm{g} / \mathrm{m}^{3}$ set by FMEnv., and $150-230 \mu \mathrm{g} / \mathrm{m}^{3}$ by WHO. However, the TSP measured during the dry season ranged from 85.9 \pm 44.6 to $277.8 \pm 213.5 \mu \mathrm{g} / \mathrm{m}^{3}$. The average correlations between $\mathrm{NO}, \mathrm{SO}_{2}$, and TSP measured during wet and dry seasons and the traffic density were 0.7 , 0.6 and 0.7 , respectively. Air pollution along the Nigerian highway is highly linked to vehicular activities.

Keywords: Vehicular, Ambient, Air Pollutions, south-western Nigerian.
Published Online: May 19, 2021

ISSN: $2684-446 \mathrm{X}$

DOI : 10.24018 /ejgeo.2021.2.3.136

\section{G. O. Adeniyi*}

Centre for Space Transport and Propulsion, LASU Campus, Lagos, Nigeria.

(e-mail:omogbadebo2002@yahoo.com)

O. I. Lawal

Advanced Aerospace Engine Laboratory, Oka, Ondo, State, Nigeria

(e-mail: deansegun ${ }^{@}$ gmail.com)

S. O. Egwenu

Centre for Space Transport and

Propulsion, LASU Campus, Lagos, Nigeria.

(Email: okeegwenu9@gmail.com)

J. A. Sonibare

Department of Chemical Engineering, Faculty of Technology, Obafemi Awolowo University, Ile-Ife, Osun State, Nigeria.

(e-mail: asonibar@yahoo.com)

F. A. Akeredolu

Department of Chemical Engineering, Faculty of Technology, Obafemi Awolowo University, Ile-Ife, Osun State, Nigeria.

(e-mail: osnyfy2k3@ yahoo.com)

*Corresponding Author

\section{INTRODUCTION}

Air remains a major source of life to mankind, but the pollution to which it has been subjected has made it become a major source of harm to man's health and his environment. The world population has been on the increase over the years [1]. In Nigeria, the population was estimated to be 140 million with a growth rate of 3.2 percent and having state growth rate ranges between 2.8-3.5\% except in Abuja [2] in 2006 compared to 88.9 million with a growth rate of 2.9 percent annum in 1991[3].

Essentially, the growing demand for fast reliable distribution of goods to support the high population and the increasing dependence on motorized vehicles for transportation have made highways a prominent facility for people to carry out their daily activities in Nigeria. These highways are characterized by several human activities, thus exposing man to the high concentration of pollutants (chemicals, particulate matter, or biological agent that modifies the natural characteristics of the atmosphere) emitted into the air from vehicles plying them. This is evident from the thick and black smoke haze found sometimes in the air along Nigeria road corridors. The adverse effects associated with human exposure to vehicular exhausts may be impaired respiratory, nervous, and reproductive system as well as kidney malfunction [4]. Airborne pollutants such as $\mathrm{SO}_{2}$ and $\mathrm{NO}_{\mathrm{x}}$ contribute to acid rain, which can destroy the forest and slowly degrade building mortar, paint, and infrastructure [5].

Pollution from motor vehicles is adversely affecting the lives of many people both around inter-cities and intra-cities highways in Nigeria [6]. Emissions from vehicles have been reported to aggravate the already elevated level of particulates, oxides of nitrogen, heavy metals, and sulfur dioxide that were generated by several human activities such as construction activities, incineration, domestic heating, and 
cooking with firewood along highways [7]. Therefore, vehicle emissions have been identified as major culprits to air pollution along highways [8].

Increased vehicular pollution in Nigeria is also traced to larger individual ownership of vehicles and tonnages of fuel consumption [1]. Single ownership of vehicles in Nigeria is influenced by improved economic conditions. More so, it has also been reported that the cost of petroleum products particularly, gasoline and gas oil are generally lower in Nigeria than in other OPEC countries, hence, also facilitating single ownership of vehicles [9]. Consequently, the rate of fuel consumption increases, which in turn increases emissions from vehicles.

Besides, the average age of vehicles in Nigeria is important when considering the vehicular pollution problems. The use of older and overused vehicles that do not meet emission standards is common in Nigeria. Owing to economic conditions, new vehicles are very expensive and only corporate organizations, the rich, and the government can acquire them. Some corporate bodies that are less buoyant even purchase used vehicles for official use [10].

Poor maintenance culture also increases the propensity of vehicles causing air pollution. Most roads in Nigeria are unpaved and those paved are not properly maintained, therefore, causing wear and tear of motor engines, brakes, and tires. As reported by [11], the implication of the above is that a high level of gaseous emissions and heavy metals are emitted to the atmosphere along with Nigeria highways. In summary, the high contribution of vehicular emissions to air quality in Nigeria could be attributed to several factors including a large number of motor vehicles, old age and overused vehicles, poor grade fuel, high fuel consumption, lack of maintenance culture, and poor maintenance of Nigerian highways [12].

Pollution arising from vehicular exhausts is mainly from the imperfect combustion of hydrocarbon fuel in engines. In the combustion process (perfect engines i.e., all the constituents of the fuel are burned with sufficient oxygen to completion during combustion) oxygen in the air would convert all the hydrogen in the fuel to water, and the entire carbon to carbon dioxide while nitrogen remains inert [13]. In reality, the combustion process cannot be perfect. Therefore, automotive engines emit several poisonous pollutants such as carbon monoxide, sulfur dioxide, toxic particulate matter (shoot), lead, and oxides of nitrogen [14]. The Perfectly operating motor vehicle engine would emit pollutants at tolerable levels [10]. However, in the real world of imperfect engines, improper fuel grades, lack of regular maintenance of vehicles and roads, physical aging of engines, and intensive use of vehicles, put constraints on perfect fuel consumption.

Though previous studies have dealt with problems of pollution from vehicle emissions in Nigerian road corridors ([15], [16], [12], and [17]), most of these studies focused on the intra-city highways and road corridors thus leaving a data gap on inter-city highways.

Ideally, when fuel is burned with the correct amount of air in a fuel-powered engine, the gases, which are left, are predominantly water vapor, carbon dioxide, and nitrogen, all of which are benign, although carbon dioxide is a greenhouse gas. This could be represented using methane fuel as illustrated in (1).

$\mathrm{CH}_{4}+2\left(\mathrm{O}_{2}+3.76 \mathrm{~N}_{2}\right) \rightarrow \mathrm{CO}_{2}+2 \mathrm{H}_{2} \mathrm{O}+7.52 \mathrm{~N}_{2}$

Deviations from this complete combustion led to the production of some unborn fuel, or components such as $\mathrm{H}_{2}$, $\mathrm{CO}$, Volatile organic compounds (VOCs), and particulate matter [18].

Diesel engines and gasoline engines are similar since both are internal combustion engines, meaning they burn the fuelair mixture within the cylinder [19]. Also, diesel engines and most petrol engines are reciprocating engines being driven by pistons moving laterally in two directions. Meanwhile, in a diesel engine, only air is compressed while fuel is then injected. Therefore, having a higher compression ratio (from 14:1 to $24: 1$ ), which is a measure of how much the engine compresses the gases in the cylinder [20]. It is heavier than a gasoline engine of the same horsepower. It is only limited by the amount of fuel injected into the cylinder. However, in a gasoline engine, the air-fuel mixture is compressed in the cylinder. The compression ratio (which controls the compression temperature) is lower compared to diesel engines (less than 10:1 or 7:1). It is limited by air fuel entering the cylinder.

Gasoline-powered vehicles tend to be the main source of $\mathrm{CO}$ emission and contribute substantially to VOCs and NOx emissions, but due to substantial improvements in emission control of new vehicles, their contribution to these pollutants is diminishing [21]. They emit only a modest amount of particulate matter (e.g., coarse particles $\left(\mathrm{PM}_{10}\right)$ and fine particles $\left.\left(\mathrm{PM}_{2.5}\right)\right)$ but ill-maintained or tampered with vehicles can emit much more. Diesel-powered vehicles, on the other hand, are substantial emitters of $\mathrm{PM}_{10}, \mathrm{PM}_{2.5}, \mathrm{SO}_{2}$, and NOx with little CO and VOCs [22].

Oxides of Nitrogen (NOx) are produced by a mechanism different from that of $\mathrm{CO}$ and exhaust VOCs. Whereas the latter are either from atmospheric nitrogen or from fuel nitrogen (i.e., product of incomplete combustion), it is generated by reactions of nitrogen and oxygen, which occur at high temperature in the presence of residual oxygen [23]. The two major oxides of nitrogen emitted from combustion systems are nitric oxide, $(\mathrm{NO})$ and nitrogen dioxide, $\left(\mathrm{NO}_{2}\right)$, and the three mechanisms of formation of $\mathrm{NO}$ are thermal $\mathrm{NO}$ (NO formed from high temperature $\left(1200{ }^{\circ} \mathrm{C}\right)$ oxidation of nitrogen found in combustion air i.e. Zeldovich mechanism) as shown in equations 2- 4, prompt NO ( NO formed by the fast reaction of hydrocarbon with molecular nitrogen in fuelrich flame (Fenimore mechanism) which could be shown in equation 5-6, and fuel NO (NO formed from nitrogen compound chemically bound in the fuel. This could be shown in equation 7 [24]. Nitrogen is always present in the combustion chamber because air is about 80 percent nitrogen. Residual fuel containing organically bounded nitrogen contributes to over $50 \%$ of the total emission of NOx. NOx is affected by the air-fuel ratio (A/F) and by engine design factors that influence temperatures, such as compression ratio, spark timing, and cooling system performance [25]. Combustion chamber deposits generally are believed to have a modest insulating effect, thus, raising combustion temperature and increasing $\mathrm{NO}_{\mathrm{x}}$ emissions slightly. 
However, reducing peak temperature in the combustion chamber, reducing the gas residence time in hightemperature zone, and reducing the oxygen concentration in the chamber set the NOx emissions under control [25].

$\underline{\text { Thermal NO }}$

$$
\begin{aligned}
& \mathrm{N}_{2}+\mathrm{O} \Leftrightarrow \mathrm{NO}+\mathrm{N} \\
& \mathrm{N}+\mathrm{O}_{2} \Leftrightarrow \mathrm{NO}+O \\
& \mathrm{~N}_{2}+\mathrm{OH} \Leftrightarrow \mathrm{NO}+\mathrm{H}
\end{aligned}
$$

\section{$\underline{\text { Prompt NO }}$}

$$
\begin{aligned}
& \mathrm{CH}+\mathrm{N}_{2} \Leftrightarrow \mathrm{HCN}+\mathrm{N} \\
& \mathrm{C}+\mathrm{N}_{2} \Leftrightarrow C \mathrm{~N}+\mathrm{N}
\end{aligned}
$$

\section{$\underline{\text { Fuel NO }}$}

Fuel $\mathrm{N} \rightarrow \mathrm{HCN}+\mathrm{OH} \Leftrightarrow \mathrm{NH}_{2}+\mathrm{CO} \Leftrightarrow N H+H_{2}$

Carbon monoxide (CO) results from the incomplete combustion of fuel and the main factor influencing its production is the ratio of air to fuel $(\mathrm{A} / \mathrm{F})$ in the combustion chamber. If the air-fuel mixture is fuel-rich i.e., has insufficient air $\left(\mathrm{O}_{2}\right)$ to convert all fuel carbon to carbon dioxide $\left(\mathrm{CO}_{2}\right)$, the exhaust will contain a high level of $\mathrm{CO}$ [26].

Volatile organic compounds (VOCs), for a variety of reasons, manage to escape from the combustion chamber unburned. These VOCs emissions (Exhaust VOCs) consist primarily of unburned hydrocarbons, but partially burned oxygen-containing compounds such as aldehydes may also be present in small quantities. The quantity of exhaust VOCs emission is influenced by many factors, including engine design, operating temperature, air-fuel ratio (A/F), system deposits, the condition of the engine and its controls, and the performance of the catalytic converter. If the vehicle has some significant malfunction that inhibits proper ignition or combustion, like a bad spark plug, VOC emissions can be many times higher than expected. VOCs emission may result from gasoline vapor that is generated due to heating of the fuel as daily temperature variations and operation of the vehicle as well as leakage from the fuel system [26]. Sulfur present in the fuel becomes sulfur dioxide in the vehicle exhausts. Fuel engines are estimated to be the source of $\mathrm{SO}_{2}$ emissions [26].

Airborne particulate matter includes dust, soot, smoke, and liquid droplet. Particulate matter is a complex mixture of organic and inorganic substances. They can be characterized by their physical attributes which include their transport, deposition, and chemical composition. Particulates exceeding 2.5 microns $(\mu \mathrm{m})$ in aerodynamic diameter are referred to as coarse particles, while particles smaller than 2.5 micron $\mathrm{PM}_{2.5}$ are called fine particles. Particulates are commonly emitted into the air along highways from various human activities, some of which are vehicular exhausts, industrial emissions, and other anthropogenic sources. Particulate matter attributable to vehicle exhausts includes primary carbon particles (mainly from diesel), secondary sulfate, and nitrate aerosols formed by the reaction of $\mathrm{SO}_{2}$ and $\mathrm{NOx}$ in the atmosphere and carbonaceous substances (graphite and soot) [27]. The gasoline fuel vehicles were the primary sources of airborne lead $(\mathrm{Pb})$ when gasoline contains the antiknock additive tetraethyl lead. However, lead emissions decrease sharply over the years, as the lead content in leaded gasoline is phased down and as the sale of unleaded gasoline increases [28]. The production of fuel containing lead additives has been finally prohibited in Nigeria. However, elements such as nickel, copper, zinc, cadmium, and vanadium can also be emitted with sulfur from vehicles and these are all potentially toxic, even at quite low concentrations [29].

Pollutants from vehicles are toxic and the human tolerance to these substances is relatively low. They constitute hazards to a large fraction of the population who are kept near vehicular emission sources during their daily activities. In addition to human health impacts, some air pollutants pose a threat to vegetation and property/assets. These pollutants are also criteria air pollutants [30]. In Nigeria, the Federal Ministry of Environment, Housing, and Urban Development (FMEnv.) regulates the concentration of pollutants in the atmosphere to which human, animal, and plants may be exposed without endangering health or welfare in the nation, thus, prescribes an Ambient Air Quality Standards for Nigeria. The details of pollutants from vehicle emissions and

\begin{tabular}{|c|c|}
\hline \multicolumn{2}{|c|}{ HEALTH EFFECTS } \\
\hline Pollutants & Primary health effects \\
\hline Nitrogen Oxides (NOx) & $\begin{array}{l}\text { Aggravation of respiratory illness } \\
\text { among infants, }\end{array}$ \\
\hline Carbon Monoxide (CO) & $\begin{array}{l}\text { Causing headaches, Dizziness } \\
\text { Reduced ability to think }\end{array}$ \\
\hline Sulfur dioxide & $\begin{array}{l}\text { Irritation of eyes, premature death, } \\
\text { morbidity. Aggravation of respiratory } \\
\text { disease among children (asthma, } \\
\text { emphysema). }\end{array}$ \\
\hline Lead & $\begin{array}{l}\text { Impairment of brain function, nerve } \\
\text { contraction, behavioral and hearing } \\
\text { problems in children. }\end{array}$ \\
\hline Particulate matter & $\begin{array}{l}\text { Increase cough and chest discomfort. } \\
\text { Reduced lung function, aggravation of } \\
\text { respiratory diseases }\end{array}$ \\
\hline
\end{tabular}
associated health effects are shown in Table 1. This paper presents the air pollutant concentrations and effects on air quality and impairment along inter-city highways.

TABLE I: POLLUTANTS FROM VEHICLE EMISSIONS AND ASSOCIATED

\section{MATERIALS AND METHODS}

\section{A. Sampling Sites}

This study involved sampling ambient air for airborne TSP, $\mathrm{SO}_{2}$, and $\mathrm{NO}_{\mathrm{X}}$ at different locations along the Ife-Ibadan highway. The ambient air sampling was carried out in ten different chosen locations $\left(S_{1}-S_{10}\right)$ along the highway from Toll-Gate Ile-Ife to Toll-Gate Ibadan with each location having two sampling points (one at each side of the road). The sampling points and locations were chosen were as shown in Fig. 1 and 2. The selection of these sampling locations was based on several criteria including proximity to vehicular emissions and other anthropogenic sources and their importance as the center of human activities such as frying.

\section{B. Sampling Period}

Atmospheric conditions changes are more pronounced between wet and dry seasons in Nigeria. The persistence of 
either of the season is influenced by the absolute fraction of time during an annual cycle that the line of the Inter-Tropical Convergence Zone (ITCZ) or the Inter-Tropical Discontinuity (ITD) is below or above its line of latitude [31]. The dry season (under the influence of the northeast trade winds, when the ITD is southward), on the average, starts around the middle of October and lasts until the middle of April of the following year, though more pronounced between mid-November and mid-February. Rains initiated by the predominance of southwest monsoon winds, dominate the remaining six months of the year when the ITD lies north. The dry season period is characterized, not only by the near absence of rain, but also by the transport of dust haze from the Sahara Desert [31]. Thus, in this research study, a twoseason sampling period was adopted.

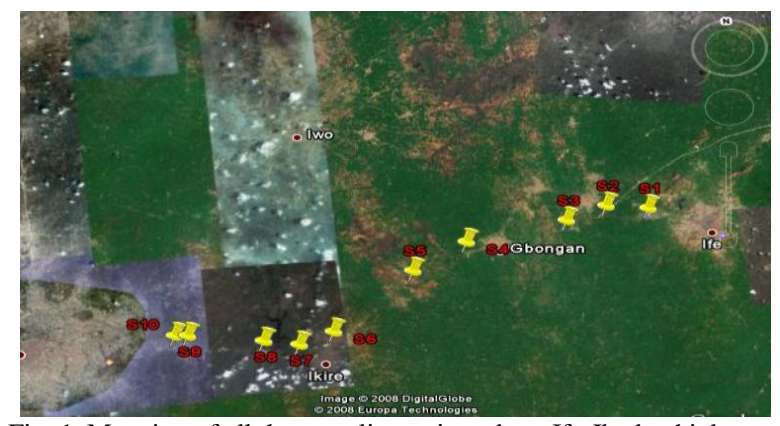

Fig. 1. Mapping of all the sampling points along Ife-Ibadan highway.

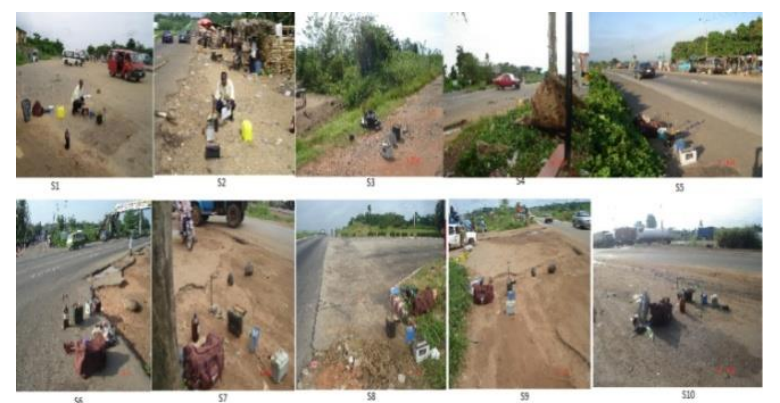

Fig. 2. Sampling locations along with Ife-Ibadan highway.

TABLE II: DESCRIPTIONS OF THE SAMPLING LOCATIONS

\begin{tabular}{|c|c|c|c|c|}
\hline $\begin{array}{l}\mathrm{S} / \\
\mathrm{N}\end{array}$ & Locations & Co-ordinates & Description of Locations & Possible Sources/or Activities \\
\hline 1 & $\mathrm{~S}_{1}$ & $\mathrm{~N} 07^{0} 29.37, \mathrm{E}^{2} 04^{0} 29.34$ & Toll-Gate Ile-Ife & $\begin{array}{l}\text { Soil entrainment, vehicular emission, metal works, and wood burning, } \\
\text { vaporized oil from cooking, construction work (petrol station), open } \\
\text { waste, and refuse burning. }\end{array}$ \\
\hline 2 & $\mathrm{~S}_{2}$ & N07 29.60, E004 27.14 & $\begin{array}{l}\text { The point joining Ife-Ibadan } \\
\text { highway to Ilesha road } \\
\text { (Roundabout) }\end{array}$ & $\begin{array}{l}\text { Soil entrainment, vehicular emission, metalwork, vaporized oil from } \\
\text { cooking, construction work (university of technology structures), open } \\
\text { refuse burning, wood and bush burning. }\end{array}$ \\
\hline 3 & $\mathrm{~S}_{3}$ & $\mathrm{~N} 07^{0} 29.13, \mathrm{E} 004^{0} 24.60$ & $\begin{array}{l}\text { The point joining Ife-Ibadan } \\
\text { highway to Akinlalu-Ipetu } \\
\text { (Akinlalu Junction) }\end{array}$ & $\begin{array}{l}\text { Soil entrainment, vehicular emission, metalwork, construction work } \\
\text { bridge), fuel evaporation from petrol stations, waste burning, and wood- } \\
\text { burning }\end{array}$ \\
\hline 4 & $\mathrm{~S}_{4}$ & N07 28.02, E004 19.55 & $\begin{array}{l}\text { The point joining Ife-Ibadan } \\
\text { highway to Gbongan-Osogbo } \\
\text { road (Gbongan Junction) }\end{array}$ & $\begin{array}{l}\text { Soil entrainment, vehicular emission, metalwork, vaporized oil from } \\
\text { cooking, waste burning, and wood-burning }\end{array}$ \\
\hline 5 & $\mathrm{~S}_{5}$ & $\mathrm{~N} 07^{0} 26.12, \mathrm{E} 004^{0} 15.51$ & Wasinmi & $\begin{array}{l}\text { Soil entrainment, vehicular emission, metalwork, wood-burning, refuse } \\
\text { decomposition, fuel evaporation from the petrol station, waste and refuse } \\
\text { burning, vaporized oil from cooking, and household heating and } \\
\text { cooking. }\end{array}$ \\
\hline 6 & $\mathrm{~S}_{6}$ & $\mathrm{~N} 07^{0} 22.48, \mathrm{E} 004^{0} 11.02$ & $\begin{array}{l}\text { The point joining Ife-Ibadan } \\
\text { highway to Ikire-Iwo road (Ikire } \\
\text { Junction) }\end{array}$ & $\begin{array}{l}\text { Soil entrainment, vehicular emission, metalwork, wood-burning, } \\
\text { residential houses, construction work (petrol station), oil and fuel } \\
\text { burning, petrol station, refuse and waste burning, and sawmills. }\end{array}$ \\
\hline 7 & $\mathrm{~S}_{7}$ & $\mathrm{~N} 07^{0} 21.16, \mathrm{E} 004^{0} 09.04$ & $\begin{array}{l}\text { The point joining Ife-Ibadan } \\
\text { highway to Ikoyi (Ikoyi Junction) }\end{array}$ & $\begin{array}{l}\text { Vehicular emission sawmills residual houses at some distance from the } \\
\text { junction, wood-burning, soil entrainment, and mechanics workshop. }\end{array}$ \\
\hline 8 & $\mathrm{~S}_{8}$ & $\mathrm{~N} 07^{0} 21.41, \mathrm{E} 004^{0} 07.05$ & Asejire bottling company & $\begin{array}{l}\text { Nigeria Bottling Company, soil entrainment, vehicular emission, wood- } \\
\text { burning, heavy oil combustion from plants, and refuse burning. }\end{array}$ \\
\hline 9 & $\mathrm{~S}_{9}$ & $\mathrm{~N}^{0} 7^{0} 22.29, \mathrm{E} 004^{0} 02.52$ & Egbeda & $\begin{array}{l}\text { Mechanic and vulcanize shops, soil entrainment, vehicular emission, } \\
\text { wood-burning, waste and refuse burning, oil vaporized from cooking, } \\
\text { petrol station, and residential houses. }\end{array}$ \\
\hline 10 & $\mathrm{~S}_{10}$ & $\mathrm{~N} 07^{0} 22.35, \mathrm{E} 004^{0} 02.12$ & Toll-Gate Ibadan & $\begin{array}{l}\text { Soil entrainment, vehicular emission, metalwork, wood burning, and oil } \\
\text { vaporization from cooking, mechanic and vulcanize workshop, refuse } \\
\text { and waste burning. }\end{array}$ \\
\hline
\end{tabular}

\section{Sampling Procedures}

A low volume air sampler was used to suck ambient air through prepared absorbents for each of $\mathrm{SO}_{2}, \mathrm{NO}_{x}$, and a weighted sampling filter (Whatman Cellulose Filter paper of diameter $2.54 \mathrm{~cm}$ ) for TSP. A Flow Meter graduated in liters of air per minute was employed to verify a stable and accurately measured continuous flow rate of air during the sampling period. The sampling train also includes a Filter Holder, which is a small and cylindrical metallic tube with an outlet for air to which plastic tubing is connected. It holds the sampling filter at an elevated height of about $1.6 \mathrm{~m}$ above the ground. The sampling filter type used was No 41 Whatman cellulose filter paper, $2.54 \mathrm{~cm}$ in diameter, already weighed in the laboratory and encased in an airtight polyester bag. The Plastic Tubing is about one meter in length and $1.0 \mathrm{~cm}$ in diameter. It serves to join the filter holder to the main unit, thus transferring suction pressure from the unit through the filter holder. Retort stand holds and elevates the filter at the desired height of $1.6 \mathrm{~m}$. At each location, the traffic volume was determined by counting manually the number of 
cars/buses, motorcycles, and Lorries that passed within each sampling period. The traffic density (Number of vehicles per hour) was also determined by dividing total traffic volume by the corresponding sampling time for each specific pollutant.

$\mathrm{NO}_{\mathrm{X}}$ was sampled at all the locations using the GriessSaltzman method. In this method, a metered volume of air was pumped through two fritted bubblers connected, each containing $10 \mathrm{ml}$ of the prepared absorbent for 30 minutes [32]-[34]. The air average flow rate was taken. All the samples were kept inside dark brown sampling bottles for analysis. The absorbance of all the samples was determined at $420 \mathrm{~nm}$ wavelength using a UNICAM UVI UV-Visible Spectrometer available at the Central Laboratory, Obafemi Awolowo University, Ile-Ife, Nigeria. Then, the concentration of nitrogen dioxide in each sample was calculated using WHO [33] method (equation (8) [33]).

$$
N O_{2 \text { conc. }}=\frac{(A)(Y)(46.0)}{(S)(V)(69.0)(0.74)}=\frac{(0.901)(A)(Y)}{(S)(V)}
$$

where, $A=$ sum of absorbance (corrected for reagent blank) for pair of bubblers, $Y=$ volume of absorbing reagent contained in one bubbler $(10 \mathrm{ml}), \quad S=$ slope of $\mathrm{NaNo}_{2}$ calibrating curve $(0.7$ absorbance per $\mu \mathrm{g} / \mathrm{ml}), V=$ standard volume of air sampled. $\left(0.1 \mathrm{~m}^{3}\right), 46.0=$ molecular weight of nitrogen dioxide, $69.0=$ molecular weight of sodium nitrite, $0.7=$ empirical factor.

The absorbent used for sampling for $\mathrm{SO}_{2}$ in this study was prepared by diluting $2 \mathrm{ml}$ of $\mathrm{H}_{2} \mathrm{O}_{2}$ containing $30 \% \mathrm{w} / \mathrm{v}$ in distilled water to 1 Liter to have a hydrogen peroxide solution containing $0.06 \% \mathrm{w} / \mathrm{v}$ in distilled water. This calculation is shown in equation 9. The $0.06 \% \mathrm{w} / \mathrm{v}_{2} \mathrm{O}_{2}$ was chosen to avoid the interference of $\mathrm{NH}_{3}$ and to allow an absorbent that will have a low blank for $\mathrm{NH}_{3}$. Then, $4.2 \mathrm{ml}$ of $0.01 \mathrm{NaOH}$ was added to the $950 \mathrm{ml}$ of the remaining absorbent. The hydrogen peroxide solution produced grey color when tested with indicator solution $(0.06 \mathrm{~g}$ bromoresol green and $0.04 \mathrm{~g}$ methyl red in $100 \mathrm{ml}$ of methanol) [33].

$$
C_{1} \times V_{1}=C_{2} \times V_{2}
$$

where $C_{1}$ is the amount of $\mathrm{H}_{2} \mathrm{O}_{2}$ in the initial solution (30\% w/v), $V_{1}$ is the amount of the initial solution to be diluted to have $0.06 \% \mathrm{H}_{2} \mathrm{O}_{2}, C_{2}$ is the amount of $\mathrm{H}_{2} \mathrm{O}_{2}$ in the diluted solution $(0.06 \%), V_{2}$ is the final volume of diluted $\mathrm{H}_{2} \mathrm{O}_{2}$ solution(1000 ml).

In this method, a metered volume of air was pumped through a fritted bubbler, which contained $50 \mathrm{ml}$ of the absorbent for 2 hours [33], [34]. The average flow rate during sampling was determined. All the samples were kept inside the dark brown sampling bottles for analysis.

The concentration of the $\mathrm{SO}_{2}$ in the air sampled was determined at the Central Laboratory, Obafemi Awolowo University, Ile-Ife, Nigeria, using a U.V method (Alpha 4, Chem. Tech Analytical 4200) also called Coulometric method [35]. In this method, $4 \mathrm{ml}$ of each sample was acidified by adding $0.5 \mathrm{ml}$ of concentrated hydrogen chloride, followed by the addition of $0.5 \mathrm{~g}$ of barium chloride. The solution was shaken vigorously until the chloride dissolved and left for 12 minutes. Then, the turbidity of each sample was read at wavelength $420.0 \mathrm{~nm}$. The concentration of $\mathrm{SO}_{2}$ ppm was calculated from equation 3.5 as:

$S O_{2_{\text {CONC }}}=A B S \times 4.4843 \times 10^{-3} \times 2 \times 10^{4}$

where $4.5 \times 10^{-3}=$ constant of the standard curve plotted; $2=$ mole ratio of $\mathrm{SO}_{2}: A B S$ is the measured absorbance; $10^{4}$ is the conversion factor from $\%$ to $\mathrm{ppm}$.

Then to microgram per cubic meter using (11) [36]:

$$
\frac{\mu g}{m^{3}}=\frac{p p m \times M W}{24.5} \times 10^{3}
$$

where $\mathrm{MW}=$ molecular weight of sulfur dioxide

TSP was measured using the Gravimetric method. The Whatman-41 cellulose filter paper of size $2.5 \mathrm{~cm}$ in diameter was specifically chosen for this air sampling study. This is because it has the lowest background concentration of the elements [37]. It is available and relatively cheap. The filter papers were acclimatized or equilibrated in desiccators for 24 hours after which their initial weights were determined. At each site, the sampler was loaded with a weighed filter paper and allowed to sample for four hours [38]-[40].

The loaded filters were re-weighed using METTER TOLEDO AB54 to determine the final weight after sampling. A blank filter was similarly handled, and filters were kept in separate polythene bags for later analysis. The concentration of the TSP present in the ambient air sampled along the IfeIbadan highway was calculated from (12).

$$
T S P=\frac{\Delta W_{P}}{\Delta V_{\text {air }}}=\frac{W_{f}-W_{i}}{V_{T}} \times 10^{6}
$$

where, TSP is the Total Suspended Particular Matters concentration $\left(\mu \mathrm{g} / \mathrm{m}^{3}\right), W_{f}=$ Final weight of the loaded filter (g), $W_{i}=$ Initial weight of the filter $(\mathrm{g}), V_{T}=$ Total volume of air sampled (i.e. the product of average flow rate and sampling time $(\mathrm{t})) .10^{6}=$ conversion factor [41].

\section{RESULTS AND DISCUSSIONS}

Table III summarizes the average concentration of $\mathrm{NO}_{\mathrm{X}}$ measured in ambient air at ten different locations along the Ife-Ibadan highway during wet and dry seasons, respectively. The concentration ranges from $9.9 \mu \mathrm{g} / \mathrm{m}^{3}$ to $33.8 \mu \mathrm{g} / \mathrm{m}^{3}$ and $16.7 \mu \mathrm{g} / \mathrm{m}^{3}$ to $35.4 \mu \mathrm{g} / \mathrm{m}^{3}$ during wet and dry seasons respectively which is generally below the applicable Nigerian ambient air quality standard limits of $75.0 \mu \mathrm{g} / \mathrm{m}^{3}-113 \mu \mathrm{g} / \mathrm{m}^{3}$ as required [35] and the guideline of $200 \mu \mathrm{g} / \mathrm{m}^{3}$ set by the World Health Organization [41] during both seasons. The annual cycle mean values of $\mathrm{NO}_{\mathrm{X}}$ concentration and traffic density are $28.7 \mu \mathrm{g} / \mathrm{m}^{3}$ and $375 \mathrm{veh} . / \mathrm{hr}$, respectively. A strong relationship exists between measured $\mathrm{NO}_{\mathrm{X}}$ concentrations and traffic density for both wet and dry seasons.

The correlation coefficient of 0.5 and 0.9 respectively were reported for both wet and dry seasons, which indicate that vehicular exhausts probably contribute significantly to the concentration of $\mathrm{NO}_{\mathrm{X}}$ present in the ambient air around each 
location along the highway. The relatively strong correlation between the traffic density and the concentration of $\mathrm{NO}_{\mathrm{X}}$ measured during the dry season as compared to the correlation value during the wet season could be attributed to the effect of precipitation of this gas in the ambient air by heavy rain which was experienced during sampling. Also, it could be an indication of additional contribution from sources such as vaporized oil from cooking and cooking with firewood which was very rampant during sampling.

The average concentration of $\mathrm{SO}_{2}$ measured in the study area during the fieldwork is presented in Table IV for both wet and dry seasons, respectively. The concentration ranged between $49.7 \mu \mathrm{g} / \mathrm{m}^{3}$ and $219 \mu \mathrm{g} / \mathrm{m}^{3}$ with the minimum at sampling location $\mathrm{S}_{4}$ and maximum at location $\mathrm{S}_{8}$ during the wet season and $89.1 \mu \mathrm{g} / \mathrm{m}^{3}$ and $225.4 \mu \mathrm{g} / \mathrm{m}^{3}$ with a minimum at sampling location $\mathrm{S}_{3}$ and maximum still at location $\mathrm{S}_{8}$ for the dry season. The average concentration of $\mathrm{SO}_{2}$ in the ambient air at all the locations for both wet and dry seasons are below the limit range of $26-260 \mu \mathrm{g} / \mathrm{m}^{3}$ set by Nigeria Federal Ministry of Environment, Housing and Urban Development [35], but above $20 \mu \mathrm{g} / \mathrm{m}^{3}$ guideline set by the World Health Organization [41]. The annual mean values of $\mathrm{SO}_{2}$ concentration and traffic density are $151.0 \mu \mathrm{g} / \mathrm{m}^{3}$ and $271 \mathrm{veh} . / \mathrm{hr}$, respectively.

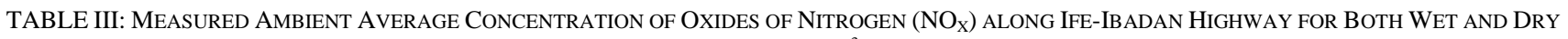
SEASON $\left(\mu \mathrm{g} / \mathrm{m}^{3}\right)$

\begin{tabular}{|c|c|c|c|c|c|c|c|c|}
\hline \multirow[b]{2}{*}{ Locations } & \multicolumn{4}{|c|}{ Wet season } & \multicolumn{4}{|c|}{ Dry Season } \\
\hline & $\begin{array}{c}\text { Total } \\
\text { Traffic } \\
\text { Volume }\end{array}$ & $\begin{array}{l}\text { Traffic Density } \\
\text { (Num. Veh./hr) }\end{array}$ & $\begin{array}{l}\text { Av. Conc. } \pm \\
\text { S.D }\left(\mu \mathrm{g} / \mathrm{m}^{3}\right)\end{array}$ & $\begin{array}{c}\text { Correlation } \\
\text { Coeff. }\end{array}$ & $\begin{array}{c}\text { Total } \\
\text { Traffic } \\
\text { Volume }\end{array}$ & $\begin{array}{l}\text { Traffic Density } \\
\text { (Num. Veh./hr) }\end{array}$ & $\begin{array}{l}\text { Av. Conc. } \pm \\
\text { S.D }\left(\mu \mathrm{g} / \mathrm{m}^{3}\right)\end{array}$ & $\begin{array}{l}\text { Correlation } \\
\text { Coeff }\end{array}$ \\
\hline $\mathrm{S}_{1}$ & 89 & 178 & $9.9 \pm 3.2$ & & 117 & 234 & $19.0 \pm 1.2$ & \\
\hline $\mathrm{S}_{2}$ & 291 & 582 & $28.6 \pm 1.4$ & & 220 & 440 & $29.0 \pm 1.0$ & \\
\hline $\mathrm{S}_{3}$ & 127 & 254 & $20 \pm 11.4$ & & 138 & 276 & $25.7 \pm 8.1$ & \\
\hline $\mathrm{S}_{4}$ & 220 & 440 & $17 \pm 3.9$ & & 204 & 408 & $18.9 \pm 2.8$ & \\
\hline $\mathrm{S}_{5}$ & 196 & 392 & $29.6 \pm 7.5$ & & 264 & 528 & $33.4 \pm 5.3$ & \\
\hline $\mathrm{S}_{6}$ & 106 & 212 & $26.2 \pm 0.4$ & 0.5 & 205 & 410 & $26.5 \pm 034$ & 0.9 \\
\hline $\mathrm{S}_{7}$ & 199 & 398 & $16 \pm 1.3$ & & 112 & 224 & $16.7 \pm 0.95$ & \\
\hline $\mathrm{S}_{8}$ & 201 & 402 & $21.1 \pm 3.2$ & & 142 & 284 & $22.7 \pm 2.3$ & \\
\hline $\mathrm{S}_{9}$ & 139 & 278 & $22.2 \pm 3.6$ & & 200 & 400 & $23.9 \pm 2.5$ & \\
\hline $\mathrm{S}_{10}$ & 260 & 520 & $33.8 \pm 3.3$ & & 315 & 630 & $35.4 \pm 2.3$ & \\
\hline Mean & 183 & 366 & $22.4 \pm 3.9$ & & 192 & 383 & $35.1 \pm 3.9$ & \\
\hline
\end{tabular}

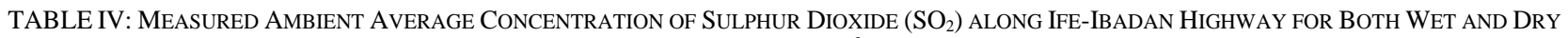
$\operatorname{SEASON}\left(\mu \mathrm{g} / \mathrm{m}^{3}\right)$

\begin{tabular}{|c|c|c|c|c|c|c|c|c|}
\hline \multirow[b]{2}{*}{ Locations } & \multicolumn{4}{|c|}{ Wet season } & \multicolumn{4}{|c|}{ Dry Season } \\
\hline & $\begin{array}{c}\text { Total } \\
\text { Traffic } \\
\text { Volume }\end{array}$ & $\begin{array}{l}\text { Traffic Density } \\
\text { (Num. Veh./hr) }\end{array}$ & $\begin{array}{l}\text { Av. Conc. } \pm \\
\text { S.D }\left(\mu \mathrm{g} / \mathrm{m}^{3}\right)\end{array}$ & $\begin{array}{l}\text { Correlation } \\
\text { Coeff. }\end{array}$ & $\begin{array}{c}\text { Total } \\
\text { Traffic Volume }\end{array}$ & $\begin{array}{l}\text { Traffic Density } \\
\text { (Num. Veh./hr) }\end{array}$ & $\begin{array}{l}\text { Av. Conc. } \pm \\
\text { S.D }\left(\mu \mathrm{g} / \mathrm{m}^{3}\right)\end{array}$ & $\begin{array}{l}\text { Correlation } \\
\text { Coeff. }\end{array}$ \\
\hline $\mathrm{S}_{1}$ & 410 & 205 & $52.4 \pm 70.5$ & & 450 & 225 & $106.1 \pm 1.8$ & \\
\hline $\mathrm{S}_{2}$ & 1012 & 506 & $206.0 \pm 121.5$ & & 1032 & 516 & $209.7 \pm 47.7$ & \\
\hline $\mathrm{S}_{3}$ & 448 & 224 & $62.6 \pm 177.7$ & & 350 & 175 & $89.1 \pm 20.9$ & \\
\hline $\mathrm{S}_{4}$ & 423 & 211 & $49.7 \pm 38.1$ & & 402 & 201 & $94.6 \pm 16.6$ & \\
\hline $\mathrm{S}_{5}$ & 415 & 207 & $177.6 \pm 11.4$ & & 520 & 260 & $201.8 \pm 133.3$ & \\
\hline $\mathrm{S}_{6}$ & 462 & 231 & $162.3 \pm 88.6$ & 0.6 & 512 & 256 & $194.3 \pm 107.8$ & 0.6 \\
\hline $\mathrm{S}_{7}$ & 301 & 150 & $124.0 \pm 27.1$ & & 360 & 180 & $100.2 \pm 5.0$ & \\
\hline $\mathrm{S}_{8}$ & 550 & 275 & $219.8 \pm 18.1$ & & 426 & 213 & $225.37 \pm 57.9$ & \\
\hline $\mathrm{S}_{9}$ & 518 & 259 & $167 \pm 92$ & & 732 & 366 & $155.8 \pm 32.8$ & \\
\hline $\mathrm{S}_{10}$ & 677 & 338 & $207 \pm 138.6$ & & 828 & 414 & $214.3 \pm 43.5$ & \\
\hline Mean & 522 & 261 & $142.8 \pm 78.4$ & & 561 & 281 & $159.1 \pm 44.2$ & \\
\hline
\end{tabular}

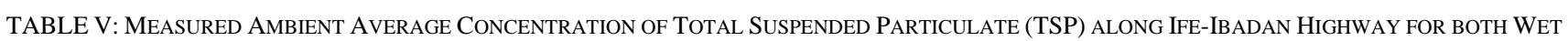

\begin{tabular}{|c|c|c|c|c|c|c|c|c|}
\hline \multirow[b]{2}{*}{ Locations } & \multicolumn{4}{|c|}{ Wet season } & \multicolumn{4}{|c|}{ Dry Season } \\
\hline & $\begin{array}{c}\text { Total } \\
\text { Traffic } \\
\text { Volume } \\
\end{array}$ & $\begin{array}{l}\text { Traffic Density } \\
\text { (Num. Veh./hr) }\end{array}$ & $\begin{array}{c}\text { Av. Conc. } \\
\pm \mathrm{S} . \mathrm{D} \\
\left(\mu \mathrm{g} / \mathrm{m}^{3}\right)\end{array}$ & $\begin{array}{l}\text { Correlation } \\
\text { Coeff. }\end{array}$ & $\begin{array}{c}\text { Total } \\
\text { Traffic } \\
\text { Volume } \\
\end{array}$ & $\begin{array}{l}\text { Traffic Density } \\
\text { (Num. Veh./hr) }\end{array}$ & $\begin{array}{l}\text { Av. Conc. } \pm \\
\text { S.D }\left(\mu \mathrm{g} / \mathrm{m}^{3}\right)\end{array}$ & $\begin{array}{l}\text { Correlation } \\
\text { Coeff. }\end{array}$ \\
\hline $\mathrm{S}_{1}$ & 719 & 180 & $54.4 \pm 25.6$ & & 807 & 202 & $87.2 \pm 46.4$ & \\
\hline $\mathrm{S}_{2}$ & 2188 & 547 & $90.6 \pm 25.6$ & & 2064 & 516 & $103.4 \pm 18.2$ & \\
\hline $\mathrm{S}_{3}$ & 809 & 202 & $54.4 \pm 25.6$ & & 736 & 184 & $87.3 \pm 46.6$ & \\
\hline $\mathrm{S}_{4}$ & 834 & 209 & $54.4 \pm 25.6$ & & 782 & 196 & $85.9 \pm 44.6$ & \\
\hline $\mathrm{S}_{5}$ & 828 & 207 & $90.58 \pm 25.6$ & & 1013 & 253 & $147.5 \pm 80.5$ & \\
\hline $\mathrm{S}_{6}$ & 697 & 174 & $54.4 \pm 25.6$ & 0.7 & 996 & 249 & $86.7 \pm 45.7$ & 0.7 \\
\hline$S_{7}$ & 607 & 152 & $54.4 \pm 25.6$ & & 708 & 177 & $79.3 \pm 35.3$ & \\
\hline $\mathrm{S}_{8}$ & 1020 & 255 & $54.4 \pm 25.6$ & & 817 & 204 & $89.4 \pm 49.6$ & \\
\hline $\mathrm{S}_{9}$ & 1154 & 289 & $90.6 \pm 25.6$ & & 1987 & 497 & $107.4 \pm 23.8$ & \\
\hline $\mathrm{S}_{10}$ & 1769 & 443 & 126.825 .6 & & 2282 & 571 & $277.8 \pm 213.5$ & \\
\hline
\end{tabular}

The strong correlation between the measured average $\mathrm{SO}_{2}$ concentration and traffic density for both seasons with $\mathrm{r}=0.6$ Suggests a high influence of vehicular exhausts on the $\mathrm{SO}_{2}$ concentration along the highway.
The mean concentrations of TSP in the ambient air measured during the wet season along the highway are presented in Table V. The mean concentrations for all the ten locations are below the Nigerian recommended ambient air 
quality standard of $250 \mu \mathrm{g} / \mathrm{m}^{3}$ [35] and range $150-230 \mu \mathrm{g} / \mathrm{m}^{3}$ World Health Organization [41]. All the sampling locations are situated at the outskirts of major towns and the highway is tarred thus reducing the propensity of dust remobilization and re-suspension. The average concentrations of TSP present in the ambient air during the season at all these locations ranged from $54.3 \pm 25.6-126.8 \pm 25.6 \mu \mathrm{g} / \mathrm{m}^{3}$ with a significant correlation existing with traffic density $(\mathrm{r}=0.7)$. Meanwhile, a similar situation was observed during the dry season, except at location $S_{10}$. However, the correlation with the traffic density was reported to be 0.7 . These suggest that particulate matter in the air could be traced to vehicular exhausts and other vehicles related sources.

\section{CONCLUSION}

The $\mathrm{NO}_{\mathrm{X}}$ concentration measured in the ambient air along Ife-Ibadan highway ranges between 9.9 \pm 3.2 and $33.8 \pm 3.3 \mu \mathrm{g} / \mathrm{m}^{3}$ during the wet season and $19.0 \pm 1.2$ and $35.4 \pm 2.3 \mu \mathrm{g} / \mathrm{m}^{3}$ during the dry season. The sulfur dioxide concentration in the ambient air also ranges between $49.7 \pm 38.1$ and $219 \pm 18.1 \mu \mathrm{g} / \mathrm{m}^{3}$, and $89.1 \pm 20.9$ and $225.4 \pm 57.9 \mu \mathrm{g} / \mathrm{m}^{3}$ during both wet and dry seasons. TSP concentration measured during both wet and dry seasons ranges between $54.4 \pm 25.6$ and $126.8 \pm 25.6 \mu \mathrm{g} / \mathrm{m}^{3}$ and $85.9 \pm 44.6$ and $277.8 \pm 213.5 \mu \mathrm{g} / \mathrm{m}^{3}$, respectively. The average correlations $\mathrm{NOx}, \mathrm{SO}_{2}$, and TSP measured during wet and dry seasons and the traffic density were $0.7,0.6$ and 0.7 , respectively. It could be concluded from this study that the emission of air pollutants is strongly attributed to vehicular activities along the Ife-Ibadan highway in Nigeria.

\section{ACKNOWLEDGMENT}

We acknowledged the numerous efforts of the entire staff of the Department of Chemical Engineering, Faculty of Engineering, Obafemi Awolowo University, Ile-Ife, Nigeria, towards the success of this study. The great assistance of the department, in the area of equipment and instrumentations are well appreciated.

\section{DisCLOSURE STATEMENT}

In accordance with our ethical obligation as researchers, we declare that this work was not financially sponsored by any organization nor operate under any research grant.

\section{REFERENCES}

[1] WHO, "Population and the Environment- The Global Challenges. Population Information Program, Centre for Communication Programs, The World Health Organization" The Johns Hopkins University School of Public Health, III Market Place, Suite 310, Baltimore, Maryland, 21202, USA, Vol. XXVIII, Number 3, 2000.

[2] NPC, "Nigeria Critique Summary Report Census Political Factors" National Population Commission, Federal Republic of Nigeria, 2006.

[3] NPC, "Cultural Diversity and Population Policy in Nigeria; Analytical Report at the National Level, Abuja." National Population Commission, Federal Republic of Nigeria, 1991.

[4] D. Schwela, "Air pollution and health in urban areas" Review Environmental Health, 15(12)13-24, 2000.
[5] M. Baciak, K. Warmiński, A. Bęś, "The effect of selected gaseous air pollutants on woody plants" Leśne Prace Badawcze / Forest Research Papers, Vol. 76 (4): 401-409, 2015.

[6] B. O. Bola, "Sources of Air Pollution and Strategies for its Management in the Nigeria Urban Cities" The Social Sciences, 1(3), 198-205, 2006.

[7] M. M. Hassan, M. A. M. B. Rabbi and O. Faruk, M. Sarwar, and P. K Roy, "Assessment of Nitrogen Oxides and Sulphur Dioxide Content in the Ambient Air near the Garments Industries of Bangladesh" Journal of Environmental and Social Sciences. Volume 5, Issue 1, 2018.

[8] USEPA, "Office of Transportation and Air Quality"-420-F-14-044, 2014.

[9] FGN, "Report of the Special Committee on Review of Petroleum Products Supply and Distribution" The Presidency, Federal Republic of Nigeria, Abuja, pp. 38-93, 2000.

[10] A. Mukoro and S.S. Ogbogu, "Air Pollution Arising from Vehicular Emissions in Lagos and the Niger Delta areas in Nigeria and the Administrative and Socio-Economic Measures for Abatement" Environtropica, 1(1): 142-151, 2004.

[11] G. M., Mafuyai, N.M., Kamoh, N. S., Kangpe, S. M., Ayuba, and. I. S Eneji, "Heavy Metals Contamination in Roadside Dust along Major Traffic Roads in Jos Metropolitan Area, Nigeria”. Journal of Environment and Earth Science Vol.5, No.5, 2015. 2225-0948 (Online), www.iiste.org ISSN 2224-3216 (Paper) ISSN.

[12] I. B., Obioh, F. S. Olise, O. K. Owoade, and H. B., Olaniyi, "Chemical Characterization of Suspended Particulate along Air Corridors of Motorways in Two Nigerian cities" Nuclear Instruments and Methods in Physics Research,5, 347-350, 2005.

[13] H. Fayaz, R. Saidur, N. Razali, F.S. Anuar, A. R. Saleman, and M. R. Islam, "An overview of hydrogen as a vehicle fuel" Renewable and Sustainable Energy Reviews, Volume 16, Issue 8, October 2012, Pages 5511-5528, 2012.

[14] UNECE, "Diesel Engines Exhausts: Myths and Realities informal document GRPE-65-05 (65th GRPE, 15-18 agenda item 17), 2013.

[15] A. G. Garba, and P. K. Garba, "Market Failure and Air Pollution in Nigeria: A Theoretical Investment of Two Cases in Selected Papers, Annual Conference Nigerian Economy Society, Held at Port-Harcourt, Nigeria" 2001. Retrieved October 2006 from World Wide Web: HTTP:// www.krepublisher.com/02_journal/JSS/JSS-08-0-000-000.

[16] P. N. Ndoke, and O. D. Jimoh, "Impact of Traffic Emission on Air Quality in a Developing City".2004. Retrieved April 2005 from World Wide Web: www.journal.au.edu/au_techno.

[17] S. O. Fakayode, and B. I. Olu-Owolabi, "Heavy Metal Contamination of Roadside Topsoil in Osogbo, Nigeria: Its relationship to Traffic Density and Proximity to Highways". Atmospheric Environment, 40(21), 3835-3844, 2004.

[18] V. V., Tran, D. Park, And Y. C., Lee, "Indoor Air Pollution, Related Human Diseases, and Recent Trends in the Control and Improvement of Indoor Air Quality” Int. J. Environ. Res. Public Health, 17(8), 2927, 2020.

[19] A., Setiawan, B., Wahono, and O. Lim, "A Study of Combustion Characteristics of Two Gasoline-Biodiesel Mixtures on RCEM Using Various Fuel Injection Pressures" Energies, 13, 3265, 2020.

[20] H. Grieshabe, and T. Raatz, "Basic Principles of the Diesel Engine" Diesel Engine Management, pp16-33, 2014.

[21] I. A., Reşitoğlu, K. Altinişik, and A. Keskin, "The Pollutant Emissions from Diesel-Engine Vehicles and Exhaust After -Treatment Systems" Clean Technologies and Environmental Policy, volume 17, pages1527, 2015.

[22] P. J., Perez-Martinez, R. M. Miranda, T. Nogueira M. L. Guardani, A. Fornaro, R. Ynoue, and M. F. Andrade, "Emission factors of air pollutants from vehicles measured inside road tunnels in $\mathrm{Sa}^{\sim}$ o Paulo: case study comparison" Int. J. Environ. Sci. Technol., 11:2155-2168, 2014.

[23] M. Semakula, and P. F. Inambao, "The Formation, Effects and Control of Oxides of Nitrogen in Diesel Engines" International Journal of Applied Engineering Research, Volume 13, Number 6, pp. 3200-3209, 2018.

[24] Bowman C. T., "Gas-Phase Reaction Mechanisms for Nitrogen Oxide Formation and Removal in Combustion. In: Vovelle C. (Eds) Pollutants from Combustion" NATO Science Series (Series C: Mathematical and Physical Sciences), vol 547. Springer, Dordrecht. https://doi.org/10.1007/978-94-011-4249-6_7, 2000.

[25] EPA, "Compilation of Air Pollutant Emission Factors" Office of Air Programs Publication No. AP42, 1977.

[26] EPA, "Natural Air Pollutant Emission Trend 1900-1998" Office of Air Quality Planning and Standards, EPA 454/R-00-002, 2000.

[27] L., Wang, J, Wang, X. Tan, and C. Fang, "Analysis of NOx Pollution Characteristics in the Atmospheric Environment in Changchun City" Atmosphere, 11, 30, 2020; doi:10.3390/atmos11010030. 
[28] M. Lovei, and B.S Levy, "Lead Exposure and Health in Central and Eastern Europe: Evidence from Hungary, Poland, and Bulgaria. Health Issues, Feasibility and Policy, Washington, D.C., World Bank”. 1997. Retrieved August 2004 from World Wide Web: http://wwwwds.worldbank.org/Servlet/WDSContentServer/WDSP/IB/2000/02/0 3.

[29] G. Kazantzis, "Cadmium; Genotoxic and Carcinogenic Metals" In: F. A. Lawrence, and A. M. Myron (eds.), Environmental Occupational Occurrence and Exposure, Advances in Modern Environmental Toxicology, Princeton Science Publishing Co, p. 11, 1987.

[30] EPA, "Automobile Emissions" An Overview. United State Environmental Protection Agency Office of Mobile Sources, EPA 400F-92-007, 1994a). Available online at HTTP: //www.epa.gov/otaq/05autos.htm, 11-21.

[31] M. O., Abdul-Raheem, F. A. Adekola, and I. B. Obioh, "Determination of Sulphur (IV) Oxide in Ilorin, City, Nigeria, during Dry Season" Journal of Applied Science, Environment and Management, 10 (2), 5$10,2006$.

[32] A. R. Ipeaiyeda, and D. A. Adegboyega, "Assessment of Air Pollutant Concentrations near Major Roads in Residential, Commercial and Industrial Areas in Ibadan City, Nigeria" Journal of Health and Pollution. 7(13): 11-21, 2017.

[33] WHO, "Selected Method of Measuring Air Pollutants", Geneva, World Health Organization, Offset Publication No 24, 1976.

[34] D. G. Palmer, "Introduction to Air Pollution" New Educational Press, pp. 46-56, 1974.

[35] FMEnv., "Guidelines and Standards for Environmental Pollution and Control in Nigeria". Federal Government Press, pp.61-65, 1991.

[36] EPA, "Guide to Environmental Issues", Doc No 52/B-94-01. United State Environmental Protection Agency, Washington, DC, USA, 1993.

[37] A. E, David, I. A. Kesiye, U. A. Stephen, A. Nimibofa, and B. A. Etta, "Measurement of Total Suspended Particulate Matter (TSP) in an Urban Environment" Yenagoa and Its Environs. JGEESI, 11(3): 1-8, 2017.

[38] O. J. Ogunsola, "Comparative Study of Environmental Automotive Pollution on Lagos and Ile-Ife" M.Sc. thesis, Department of Physics., O.A.U., Ile-Ife., 1995.

[39] I. Latinwo, "Source-Receptor Characterization of the Particulate Emission in Delta Steel Complex", Ovwian Aladja, Waari, and its Environ. M.Sc. thesis, Department of Chemical Engineering, O. A.U., Ile- Ife, Osun, Nigeria, 1996.

[40] F. S. Olise, "Determination of Concentration of Toxic Metals in the Ambient Air in Lagos and Ile-Ife, Nigeria Using Total Reflection Xray Fluorescence Technique". M.Sc. thesis, Department of Physics, O.A.U., Ile- Ife, 2003.

[41] WHO, "Air Quality Global Update" A Report on a Working Group Meeting, Bonn, Germany, EUR/05/5046029. The World Health Organization, 2005.

Gbadebo Omoniyi Adeniyi is the head, Rocket Propellant Unit, Centre for Space Transport and propulsion, Epe, Lagos, Nigeria. He has a Ph.D. in Chemical Engineering from Obafemi Awolowo University, Ile-Ife, Nigeria. Masters in Aerospace Instrumentation from SUAI, Russian Federation and Masters in Chemical Engineering from O.A.U, Ile-Ife. He specializes in rocket propulsion and air quality analysis. He is a registered member of the Council for the Regulation of Engineering in Nigeria (COREN-R41651).

Lawal, Ismail Olusegun (Ph.D.) is an Assistant Chief Scientific Officer at the Advanced Aerospace Engines Laboratory. His research interest includes multisensory data, information integration/fusion, wireless communication, multiscale estimation theory, distributed systems and networks, uncertainty models, knowledge representation, and robust knowledge-based signal/ image processing and pattern recognition. He has authored more than ten papers and teaches in postgraduate school.

Samuel Okemute Egwenu is a senior engineer at the Centre for Space Transport and Propulsion, Epe, Lagos, Nigeria with competencies in formulating solid rocket propellants of different grain geometries to meeting specific flight designs. He holds a B.Sc. degree in Chemical Engineering from Obafemi Awolowo University, Ile-Ife, and M.Sc. in Chemical and Polymer Engineering from Lagos State University, Ojo, Lagos. He is a registered member of the Council for the Regulation of Engineering in Nigeria. (COREN-R46347).

Jacob Ademola Sonibare is a professor of Chemical Engineering, Obafemi Awolowo University, Ile-Ife, Nigeria. He is a consultant in air quality and life cycle analysis.
Funso Alaba Akeredolu is a professor of Chemical Engineering, O.A.U., Ile-Ife, Nigeria. He is a certified engineer and a consultant in air quality and life cycle analysis. 